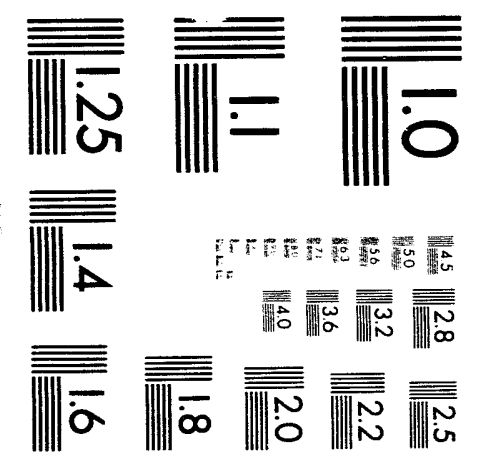



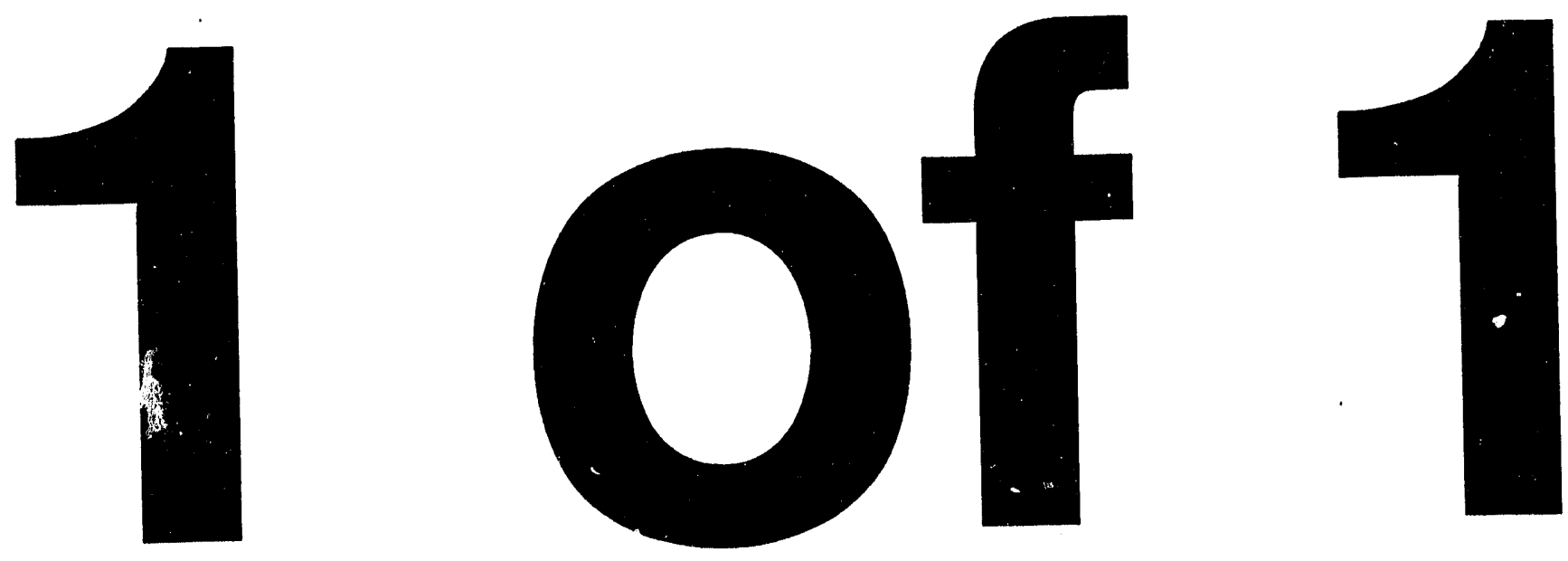


\title{
Elevated Temperature Effects on Concrete Properties
}

\author{
P. R. Grant \\ R. S. Gruber \\ Fluor Daniel, Inc.
}

C. Van Katwijk

Westinghouse Hanford Company

Date Published

August 1993

To Be Presented at

Natural Phenomena Hazards

Mitigation Conference

Atlanta, Georgia

October 19-22, 1993

Prepared for the U.S. Department of Energy

Office of Environmental Restoration and

Waste Management

\section{(W) Westinghouse




\title{
ELEVATED TEMPERATURE EFFECTS ON CONCRETE PROPERTIES
}

\author{
P. R. Grant \\ R. S. Gruber \\ Fluor Daniel, Inc. \\ 3333 Michelson Drive \\ Irvine, California 92730 \\ C. Van Katwijk \\ Westinghouse Hanford Company \\ 3333 Michelson Drive \\ Irvine, California 92730
}

\begin{abstract}
The design of facilities to process or store radioactive wastes presents many challenging engineering problems. Such facilities must not only provide for safe storage of radioactive wastes but they must also be able to maintain confinement of these materials during and after natural phenomena events.

Heat generated by the radioactive decay of the wastes will cause the temperature of the concrete containment structure to increase to a magnitude higher than that found in conventional structures. These elevated temperatures will cause strength-related concrete properties to degrade over time. For concrete temperatures less than $150^{\circ} \mathrm{F}$, no reduction in strength is taken and the provisions of $\mathrm{ACI} 349$, which states that higher temperatures are allowed if tests are provided to evaluate the reduction in concrete strength properties, apply.

Methods proposed in a Pacific Northwest Laboratory (PNL) report, Modeling of TimeVariant Concrete Psoperties at Elevated Temperatures, can be used to evaluate the effects of elevated temperatures on concrete properties. Using these modified concrete properties the capacity of a concrete structure, subjected to elevated temperatures, to resist natural phenomena hazards can be determined.
\end{abstract}

\section{INTRODUCTION}

An underground reinforced concrete vault was designed to provide interim storage for 2,000 stainless steel canisters filled with vitrified high-level radioactive wastes. Heat generated by radioactive decay of the canister contents will raise the internal temperature of the vault and the temperature of the vault's concrete above that found in normally designed buildings.

Codes such as ACI 349 [1] linit the long-term operating temperature of concrete structures to $150^{\circ} \mathrm{F}$. Higher temperatures may be allowed if tests are provided to evaluate the reduction in strength and this reduction is applied to the design allowables. It is required by DOE-STD-1020-92 [2] that if material strengths are expected to decrease over the life of the structure, then code allowable strengths should be reduced to account for this degradation.

To meet the requirements of $\mathrm{ACl} 349$ and DOE-STD)-1020-92, a thermal analysis was performed to determine the temperatures that the concrete vault will experience during its service life and what effect those temperatures will have on the strength and serviceability of the concrete. The design of the facility to withstand natural phenomena hazards and other design basis accidents was based on the lower concrete strength and serviceability properties.

\section{FACILITY DESCRIPTION}

This interim storage vault is approximately $165 \mathrm{ft}$ by $175 \mathrm{ft}$ and is embedded approximately $50 \mathrm{ft}$ into the ground. 
The vault is divided into three cells connected at the ends by intake and exhaust plenums. The top of the vault's roof is at grade level to allow access, with the use of a heavy shielded canister transporter (SCT), for the installation and removal of canisters through shield plugs in the vault roof.

A natural convection cooling system is provided to control the temperature of the stored vitrified wastes and to limit the maximum temperature that the concrete structure will experience. The cooling system is composed of two intake structures (stacks) located at one end of the vault and a single exhaust stack located at the opposite end of the vault.

This interim storage vault has a specified service life of 40 years.

\section{CONCRETE TEMPERATURES}

Because the vault cooling system is passive and convection driven, surface temperatures and through wall thermal-gradient variations within the fully loaded vault are dependent primarily on the ambient temperature of the intake air. Heat transfer and fluid flow analysis of the vault cooling system have established the relationship between the ambient air temperature and the vault concrete surface temperatures.

Climatological data for the Hanford Site representing 90 years was used with the heat transfer and fluid flow analysis to determine (1) concrete temperature ranges and their durations for establishing concrete properties, and (2) extreme temperature time histories to establish wall temperatures and gradients for stress analyses.

The relationship between the ambient air temperatures and concrete temperatures was used to determine the threshold temperatures, i.e., ambient air temperatures at which the concrete temperatures exceed $150^{\circ} \mathrm{F}$, at various points within the vault. From the climatological data and threshold temperatures, the total duration and average temperature that the concrete will be above $150^{\circ} \mathrm{F}$ throughout the vault's 40-year service life was established.

The vault operating temperatures were found to vary between $-27^{\circ} \mathrm{F}$ and $200^{\circ} \mathrm{F}$ with average operating temperatures at various places within the range of $50^{\circ} \mathrm{F}$ to $120^{\circ} \mathrm{F}$

\section{CONCRETE PROPERTIES}

An extensive search of existing literature was performed to establish the validity of the use of structural concrete at temperatures above $150^{\circ} \mathrm{F}$, and a relationship between design properties and temperature duration. The Portland Cement Association Construction Technology Laboratory was engaged as a consultant to assist in and review the effort of establishing appropriate design properties.

Conventional concrete is subject to significant transformations when subjected to elevated temperatures. Aggregates may be subject to crystal transformations leading to increases in volume or shrinkage associated with dehydration. Changes associated with the concrete aggregates seem to occur above $500^{\circ} \mathrm{F}$ and are not considered significant for this application [3].

Changes in hardened cement begin at low and moderate temperatures and continue over time. At ambient temperatures, $30 \%$ to $60 \%$ of the volume of cement paste and between $2 \%$ and $10 \%$ of the volume of concrete are occupied by free or evaporative water. As the temperature increases, this free water is lost until at about $220^{\circ} \mathrm{F}$ all the free water is lost. Above $220^{\circ} \mathrm{F}$, and with sufficient exposure, chemically combined water will be driven out until dehydration is complete at approximately $1550^{\circ} \mathrm{F}$ [3].

Based on the loss of hydrated water at temperatures above $220^{\circ} \mathrm{F}$, it was decided to limit the long-term exposure of structural corcrete to $200^{\circ} \mathrm{F}$. Low-temperature refractory concrete was placed adjacent to the vault roof and walls adjacent to the canisters. The refractory concrete served to limit the long-term exposure of the structural concrete to temperatures below $200^{\circ} \mathrm{F}$ and to attenuate thermal stresses caused by daily ambient temperature variations. See Figures 1 and 2.

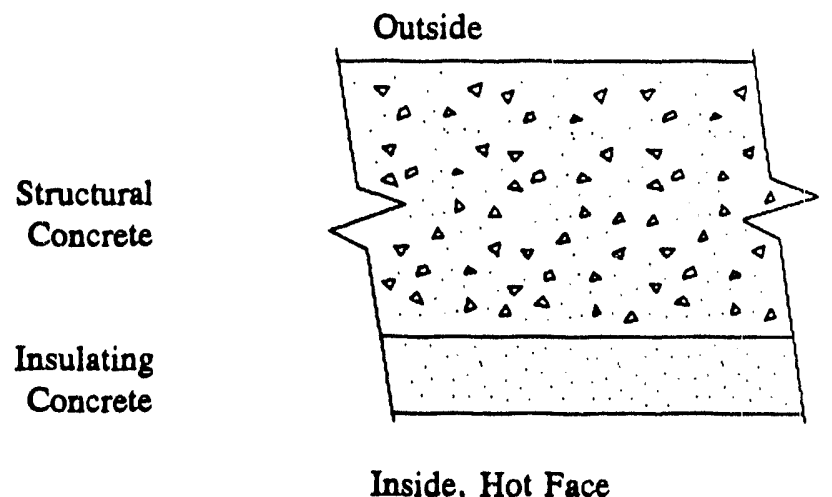

Figure 1. Vault Roof Cross Section.

Extensive literature establishing the properties of concrete exposed to short-term elevated temperatures such as fires was found. However, scant literature was found to establish design properties for concrete exposed to the longterm elevated temperatures anticipated in this vault. 


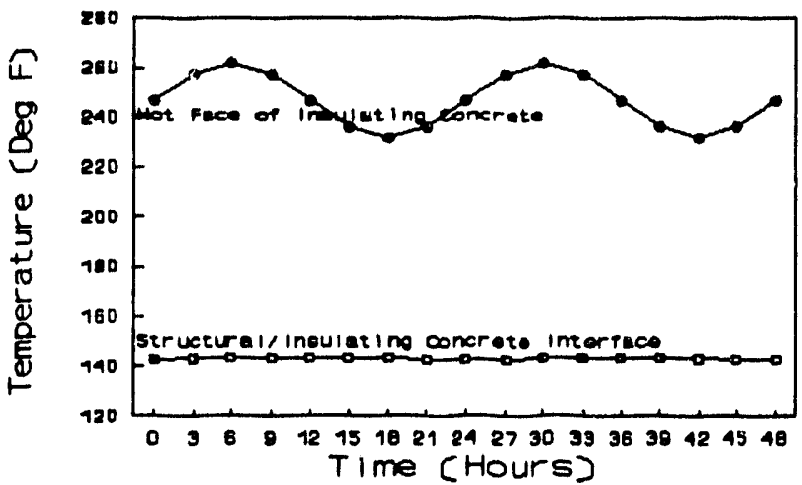

Figure 2. Insulating Concrete, Daily Temperature Variations.

The most applicable document found was the PNL report, Modeling of Time-Variant Concrete Properties at Elevated Temperatures [4]. This report is an analysis by the Portland Cement Association of a series of tests on concrete exposed to temperatures as high as $450^{\circ} \mathrm{F}$ for periods of nearly 3 years at the Hanford Site in Washington State.

The three properties that are most significant in the design process are compressive strength, modulus of elasticity, and creep coefficient. Concrete strength is used for normal flexural and axial load design. Modulus of elasticity and creep coefficient are used for calculating the deflection in the vault roof subjected to moving loads from the heavy SCT.

The predicted time-dependent and temperature-related modulus of elasticity and strength can be determined directly from the PNL report. The equations take the following form:

$$
\begin{aligned}
E= & 5.3947+0.1233 S-0.006751 T-0.1786 \log (t+1) \\
f_{c}^{\prime}= & 4416.338+490.919 S-4.714 T A-230.241 \\
& \log _{e}(t+1)+1.273 T B \log _{e}(t+1)
\end{aligned}
$$

where

$$
\begin{aligned}
& E=\begin{array}{l}
\text { predicted value of modulus of elasticity } \\
\left(10^{6} \mathrm{psi}\right)
\end{array} \\
& \mathrm{f}_{\mathrm{c}}^{\prime}=\text { predicted value of compressive strength (psi) } \\
& \mathrm{S}=\begin{array}{l}
\text { nominal initial compressive strength of } \\
\text { concrete }\left(10^{3} \mathrm{psi}\right)
\end{array} \\
& \mathrm{T}=\operatorname{constant} \text { value of temperature }\left({ }^{\circ} \mathrm{F}\right) \\
& \mathrm{TA}=\max [0, \mathrm{~T}-350]\left({ }^{\circ} \mathrm{F}\right)
\end{aligned}
$$

$$
\begin{aligned}
\mathrm{TB} & =\max [0,350-\mathrm{T}]\left({ }^{\circ} \mathrm{F}\right) \\
t & =\text { time at constant temperature (days). }
\end{aligned}
$$

Figures 3 and 4 show the reductions in properties of concrete subjected to continuously elevated temperatures for several years.

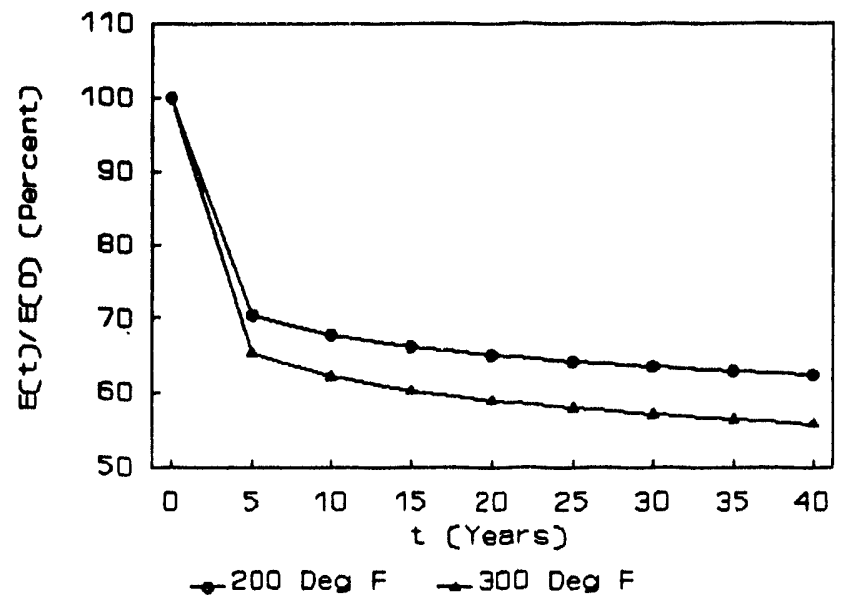

Figure 3. Modulus of Elasticity.

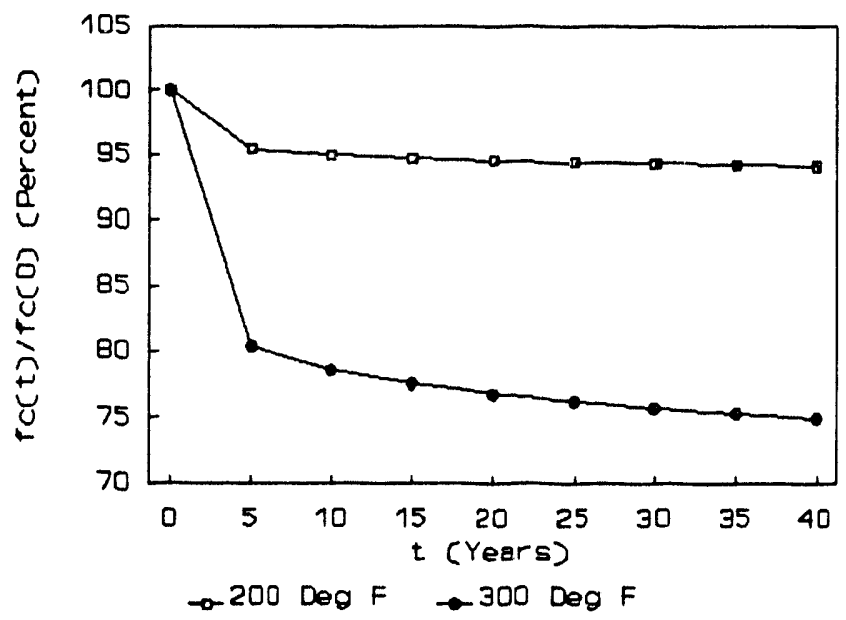

Figure 4. Compressive Strength.

The design concrete properties are extrapolations to 40 years of concrete properties measured after 3 years of exposure to elevated temperatures. Due to the uncertainties of this extrapolation, conservative reductions corresponding to exposures of approximately $250^{\circ} \mathrm{F}$ for 40 years were chosen.

The vault base mat and walls were designed for $f_{c}^{\prime}=$ $4,000 \mathrm{lbf} / \mathrm{in}^{2}$ while the compressive strength was specified to be $5,000 \mathrm{lbf} / \mathrm{in}^{2}$ at 90 days. The vault roof, subjected to 
the loads from the heavy SCT, is sensitive to immediate and long-term deflections. To control deflections in the vault roof, an increased design compressive strength of $5,000 \mathrm{lbf} / \mathrm{in}^{2}$ with a specified compressive strength of $6,000 \mathrm{lbf} / \mathrm{in}^{2}$ at 90 days was chosen for the vault roof. The vault is not expected to be in service for several years after completion. Therefore, the specification of the strength at 90 days allows the concrete to gain its specified strength with a more economical, lower cement content mix.

Additionally, to control deflections, long-term creep had to be considered in the design of the vault roof. At low to moderate temperatures, creep originates in the cement paste and represents the mutual approach of adjacent particles of cement gel while driving out water in the gaps between the particles. Temperature affects creep rate by facilitating the diffusion of water from the paste and by dehydrating free and hydrated water [3]. Creep is accounted for by factoring the immediate deflections by the "creep coefficient," ACI 349, 9.5.2.5. Creep rates reported in the PCA testing [5] were compared with other reported rates [6]. At the temperature ranges anticipated in the design, a "creep rate maximum" or creep rate greater than that found at higher and lower temperatures was found in both the testing and literature search. See Figure 5.

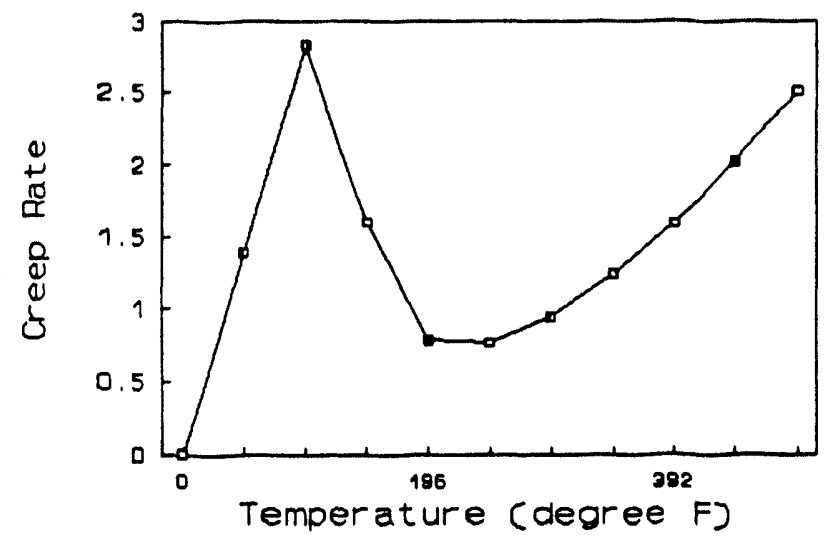

Figure 5. Local Creep Rate Maximum.

This creep rate maximum may be associated with an optumal low free water viscosity in the anticipated temperature ranges. Using the elevated creep rate, a creep coefficient of 4 (two times that required by $A C I$ 349) for the 40-year exposure was estimated. The European model concrete code committee (CEB) [7] provides methods for estimating creep and shrinkage as a function of stress, member size, temperature, humidity, and age. The creep coefficient estimated by this method corresponded closely to that developed from the measured creep rates.

\section{STRESS ANALYSIS}

Besides the mechanical and environmental loading to which the vault is subjected, the heat source and ambient thermal cycling creates significant thermal stresses.

Through-section gradients are caused by both steadystate conditions with heat flux not equal to zero, and by time-variant transient conditions. Maximum gradients may be estimated by the superposition of the maximum gradients caused by the change of temperature with respect to time on the steady-state gradient. It is anticipated that it will require 2 years to fill the vault to its design capacity. The heat source is added to the vault so slowly that it can be considered to be steady state, and no time-variant heat loading for the source needs to be considered. However, because the vault is cooled by natural convection, significant transients are caused by the daily and seasonal inlet air temperature variations.

Transient heat-transfer analyses were performed which indicated that the vault, due to the phase lag between surface and internal concrete temperatures, was unresponsive to daily temperature fluctuations (see Figures 1 and 2). Only ambient temperature changes that were maintained for days would affect the internal concrete temperatures.

The climatological data were reviewed to establish a "design heat wave" that combined a very bigh rate-ofchange in ambient temperature with a sustained period of a high daily average temperature. A heat-transfer analysis using the design heat wave as the driving function was performed on the vault. The maximum gradients produced by the design heat wave were applied to the vault using conventional finite element methods. The loading determined by the thermal gradients and elevated temperatures were combined with other mechanical load using the operating temperature combinations of ACI 349.

\section{CONCLUSION}

In recognizing that elevated temperatures decrease the strength and serviceability of concrete structures over a period of time, a study was performed to determine the temperatures of the structural concrete during the design life of the vault. Once the temperatures were determined, an evaluation was made to determine the impact of these temperatures on the strength and serviceability of the concrete.

Based on informal consultations with experts in this field, a literature search, and working directly with a 
consultant, a methodology was developed to predict the design strength of the concrete at the end of 40 years. The design of the vault to resist the applied operational, thermal, and natural phenomena loads then proceeded based on the reduced concrete properties. As a result, it is believed a structure now exists that will perform its design function for its entire design life.

\section{REFERENCES}

[1] American Concrete Institute, Code Requirements for Nuclear Safety Related Concrete Structures, ACI 349R-85, Detroit, Michigan, March, 1986.

[2] U.S. Department of Energy, Natural Phenomena Hazards Desion and Evaluation Criteria for Department of Energy Facilities, DOE-STD-1020-92, final draft, Washington, D.C., February, 1993.

[3] Naus, D. J., A Review of the Effects of Elevated Temperature on Concrete Materials and Components with Particular Reference to the Modular HighTemperature Gas-Cooled Reactor (MHTGR), Pressure Vessel Technology Section, Oak Ridge National Laboratory, March, 1988.

[4] Henager, C. H., Modeling of Time-Variant Concrete Properties at Elevated Temperatures, Pacific Northwest Laboratory, Richland, Washington, April, 1988.

[5] Portland Cement Association, Effects of Long-Term Exposure to Elevated Temperatures on the Mechanical Properties of Hanford Concrete, Construction Technology Laboratory, Richland, Washington, October, 1981.

[6] Geymayer, H. G., Effect of Temperature on Creep of Concrete; A Literature Review, American Concrete Institute, SP-34.

[7] Comite Euro-International du Beton, CEB-FIP Model Code 1990, Bulletin D'information, No. 203, Lausanne, July, 1991. 


\section{DISTRIBUTION}

Number of Copies

OFFSITE

4

Fluor Daniel. Inc. 3333 Michel son

Irvine, California 92730

P. R. Grant (2)

R. S. Gruber (2)

\section{ONSITE}

5

U.S. Department of Energy. Richland Operations office

R. W. Brown (5)

R3-73

17

West inghouse Hanford Company

L. R. Burks

P. Felise

J. R. Phillips

C. Van Katwijk (10)

Document Processing Center

Information Release Administration

(3)

G6-14

G6-06

G6-06

G6-06

G6-51

A3-36 

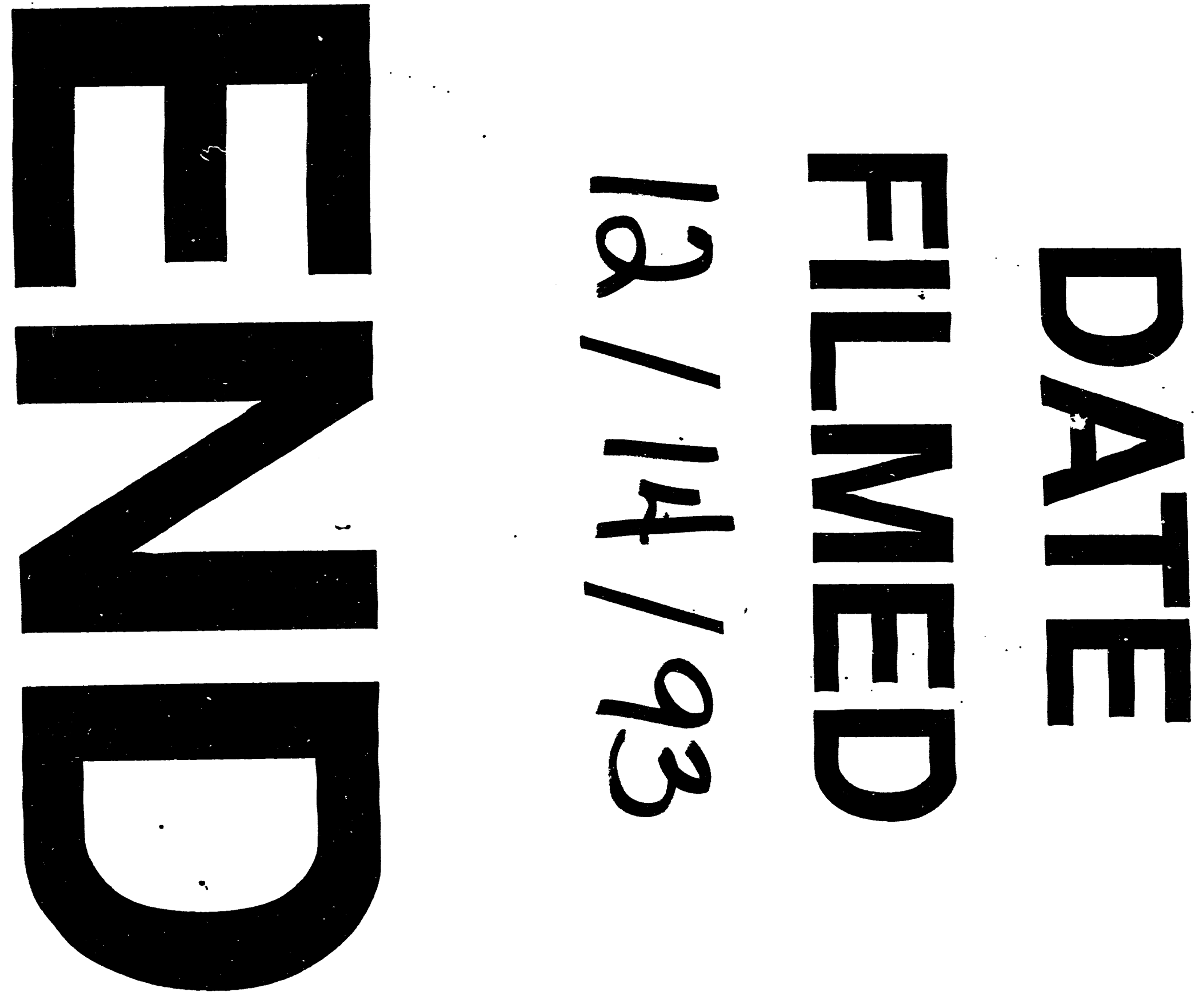


$$
\text { - }
$$

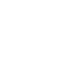
. 